\title{
ORALITY AND WRITING AMONG THE BUGIS ${ }^{1}$
}

\author{
Christian Pelras ${ }^{2}$ \\ Translated by Campbell Macknight ${ }^{3}$ \\ Australian National University, Australia \\ email: macknight@ozemail.com.au
}

Published online: 15 September 2016

To cite this article: Pelras, Ch. 2016. Orality and writing among the Bugis, trans. Macknight, C. C. In Orality, writing and history: The literature of the Bugis and Makasar of South Sulawesi, ed. Druce, S. C. International Journal of Asia Pacific Studies 12 (Supp. 1): 13-51, http://dx.doi.org/10.21315/ijaps2016.12.s1.3

To link to this article: http://dx.doi.org/10.21315/ijaps2016.12.s1.3

\section{SOME PRELIMINARY REMARKS ON WRITTEN LITERATURE IN GENERAL}

The phrase "oral literature" is most often used to indicate the forms of expression to be found either in societies without writing or in parallel with a great tradition of written literature. In both cases a comparison, indeed an opposition, seems to be implied, at the base of which really lies a particular concept of written literature. This concept is very much at risk of being unconsciously influenced by features which belong only to the written literature of certain "great civilisations," in particular modern Western civilisation. It therefore seems necessary first to look briefly at these features before tackling the case of the Bugis where oral expression coexists with written expression; this written expression is important, but has notably distinct characteristics. ${ }^{4}$

\section{Recognising a Literature}

In the West today, the only written works which are generally considered to be undeniably literary are those recognised as such by the consensus of a significant part of the intellectual class. At the heart of this class are various specialists - literary critics, teachers of literature, authors of works on 
literature and scholarly textbooks - and they exercise a determining influence in this matter. Already a good part of what is written seems to be immediately outside the field of literature-private correspondence, personal notes, reports and professional writing. The same holds for printed materials - posters, leaflets, publicity brochures, forms, technical notes, legal texts, magazine and newspaper articles, specialist works, scholarly books, practical reminders, travel guides, political discussions, religious or philosophical treatises. Of course it could happen that occasionally some of these materials are recognised as literature (certain personal letters or diaries, the articles of certain outstanding journalists or the writings of certain naturalists, and so forth), but then they will be claimed to conform with particular requirements, above all in form. These requirements are set by a substantial proportion of the intellectual class and make up precisely the basis for this consensus. On the other hand, some other works, whatever their literary pretensions, will fail to achieve the recognition hoped for since they do not fully satisfy these same requirements. They will swell the enormous body of writing judged mediocre, facile or, at best, minor. Public success does not count here as a significant criterion; thus, Guy des Cars, a prolific French author of popular novels in the 1970s, may be read by millions, but it would be hard to find a French intellectual willing to enter this author's works on the honour roll of contemporary French literature. At most, it might be agreed to include these works under the condescending heading of "popular literature"-along with a whole bundle of books (detective and spy novels, science fiction, comic strips and sentimental tales) which, while enjoying a very large sale, completely fail to meet the rules or canons implicitly understood for "great literature."

Naturally, these canons slowly change and this allows certain works from the past to emerge from "purgatory," while others fall back there. Overall, however, the list of winners fixed by generations before us can be seen as almost unchanging, and leaving aside any question of personal taste, we can say that the categorisation of earlier authors as great writers, minor authors or scribblers is hardly threatened by heart-wrenching revision. For contemporary authors, distinctions are less clear, but the development of institutions such as literary prizes seeks to promote exactly this process of ranking.

"Literature" is, then, for us a sort of idealised corpus or collection, a kind of imaginary library whose shelves are pretty well filled up for the past, while for the present there is a preliminary selection of books on temporary shelving, waiting for the final verdict of posterity. Our system of judgement can, moreover, be described as "classic" in so far as it is the artefact of a group of intellectuals, dominated by teachers, who busy 
themselves in spreading and in perpetuating the system's criteria by means of academic instruction.

\section{The Creation of Writing}

In our written literature, the author occupies a dominant position. Often a professional or a specialist in literature himself, he usually belongs to the intellectual class and even plays a dominant role in it. His personality is of great importance, for it colours all his output on which he imprints his own style and where he expresses, directly or indirectly, his personal feelings, his vision of the world and his moral, philosophical or specifically literary ideas. As a writer, he seeks in every instance to produce original work and to leave a mark on the literature of his age. Similarly, the academic study of past writers accords importance to their life.

Hence, all literary work is usually signed. Anonymous publication only occurs in so far as the content, whether in its moral, social or political implications, runs that precise risk of revealing to the light of day some aspect of the author's personality which he would rather have kept hidden.

\section{The Text}

In our literature, once a text has been written, it enjoys the status of being, as it were, untouchable. Given the relationship just emphasised between an author and his work, it is clear that no-one, if he is not the author, could legitimately modify the work to even the smallest extent, and for that to happen is all the more uncommon when the written material has been printed. For older texts of which there are several manuscript versions, or even printed versions, the scholarly editor will seek to establish the version which best fits what he thinks to have been the intentions of the author. In the case of an anonymous work, one will seek to break through to the identity of the work's creator. Plagiarism will be considered an abomination, since what the plagiarist does is to offer as his own the work of others. The plagiarist usurps part of the very personality of another.

\section{Reproduction and Distribution}

Undoubtedly one of the essential characteristics of our literature is that it is a printed literature. Printing allows, in practice, not only completely faithful and consistent reproduction, but also a very wide distribution by means of relatively cheap copies in bulk numbers. Thus, a newly published work can be made available to the public almost immediately throughout the whole 
relevant language area. As for more highly valued works, and in particular the great works of the past, they may be subjected to many republications which put them on the doorstep of virtually all their potential readers. Schools, moreover, take the responsibility (or at least they used to take the responsibility until recent years) of making known what ought to be known. What French adult has never read Le loup et l'agneau, Le Cid, Le bourgeois gentilhomme, or Après la bataille?

\section{Public Access to Works}

The normal means of accessing our literature is individual, silent reading. Even theatrical works, and above all those which have been consecrated by posterity, are probably better known to the general public in that form than in performance. As for public readings - poetry recitations for examplethey are extremely rare in our society.

The person who likes reading, then, builds up his own library whose quality can be assessed in so far as it approaches the ideal library described above, taking into account, of course, the reader's personal tastes.

\section{THE POSITION OF ORAL LITERATURE IN RELATION TO WRITTEN LITERATURE}

Taking as a point of reference the characteristics set out in the previous section as they relate to "great literature," the contrast with oral literature seems very pronounced. ${ }^{5}$

\section{Literary Recognition}

The recognition of certain forms of oral expression as "literature" is quite recent and is still far from being universally accepted. This recognition is also the doing of members of the intellectual class, but for the moment they are only a minority. Moreover, their role as judges of quality is very different from what we have seen to be the case with written literature; this "oral literature" has been created in complete independence of them and of the canons which they have established and which allow distinctions between "good" and "bad" oral literature, or "great texts" and "minor texts," or the imposition of a kind of "good taste" on the audience in the same way as that has been done for "great literature." It may be that oral literature too has its conventions and rules, but they are implicit and are only discovered by analysis; there is no how-to-do-it manual, no Art of Poetry and no-one 
has produced an artificial code to obey. If there are criteria for judging, the real judgement, and in this case the proper application of the criteria, is by the audience. This is why one can characterise this literature, and in this instance with no pejorative connotation, as "popular literature."

Another contrast with our written literature, which restricts itself to a limited number of explicitly literary genres within the vast range of written expression known to us, is that, within oral expression, there is no area which proclaims itself as literary. It is the external observer who, whether following the model of written literature or not, defines a field of which the bounds are only set arbitrarily. From this there may be some doubt when the question arises of agreeing on the criteria which would allow one to include or exclude from the field such-and-such a genre.

In this situation, there can be no "classic" tradition for oral literature, except for that which has been rendered into written form, losing by that transposition more or less of its proper oral character, in order to become a work of written literature (Perrault, Grimm, etc.).

\section{The Preeminent Role of the Author}

The character of the text in oral literature is ephemeral in that it only exists for the instant at which it is spoken. By contrast, the written text can last intact even after centuries of neglect. For the oral text, however, a whole gradation may be allowed between oral expression which is truly one-offfor example, the political speech improvised to meet a very specific occasion - and repeating the words of extremely formalised items - prayers, formulas, traditional songs, etc. (The repetition makes them particularly likely to be written down.) There are all sorts of intermediate cases. Be that as it may, however, there exists no exclusive link between these oral texts and particular authors laying claim to individual ownership. If there are several versions of an oral text in existence, none is the "right" one.

If the central figure in written literature is the author, in oral literature this role is taken by the performer. The oral text gains life through the performer whether he composes it completely at that instant, or whether he works faithfully within a received tradition or by adapting it to his own personality, or whether he recites the text of a formula learned by heart. Whatever the balance, however, between recitation and personal composition, what matters to the listener is the text just as it is as he hears it; if the performer is clever, it matters little whether he is or is not the author. In contrast with what is allowed in our written literature, the rule in this case is anonymous composition and the possibility of composition being progressive and collective. 
Moreover, the distribution being "from mouth to ear," from one performer to a relatively limited number of listeners, a specific case-even if it turns out to be a formula or the fixed words of a song-scarcely gets beyond certain limited boundaries, whether the limits are geographical or social. On the other hand, the versions and, still more, the themes prove capable of astonishing journeys across countries, cultures and continents.

\section{Public Access to Texts}

In contrast with the reader of written works of literature, whose activity is essentially solitary (even if it is not free of social implications), the person listening to oral literature is above all involved in a collective undertaking which involves personal contact with the performer and shared experience with the rest of the audience.

Another difference is that, if he is not a performer himself, it is impossible for the listener to build up a personal collection of works in the way that a reader can with his library. The only collections of works belong to the performers who form, in a way, the living public libraries of oral literature. Moreover, the concept of an idealised corpus or collection of works only really arises with the appearance of written anthologies and in fact these are merely responses to interest introduced from outside.

\section{TRADITIONAL FORMS OF BUGIS EXPRESSION: IS THERE A BUGIS LITERATURE, WHETHER WRITTEN OR ORAL?}

The above question may seem to be a strange one on the part of someone who has some time ago written a small "Introduction to Bugis literature" ${ }^{6}$ and who gives lectures on the subject at the Institut National des Langues et Civilisations Orientales. One thing, however, is certain and that is that the Bugis language has no term comparable with the Indonesian sastra (derived from Sanskrit via Javanese) and which we might translate with the French littérature (or English, literature). In practice, and since it is very proper to use a common term for comparable things, the observer cannot avoid including within this definition certain features of Bugis cultural behaviour which one would otherwise describe as literary. It is also proper, however, to avoid as far as possible bringing to these features connotations with which we are familiar in our civilisation.

There are, indeed, all kinds of writings which, for convenience, can be placed in the category of "written Bugis literature." There are also all kinds of forms of oral expression which can be placed, for the same reason, 
in the category of "oral Bugis literature." It is, however, possible to demonstrate that many of the characteristics which, elsewhere, belong to written literature do not occur in the Bugis case where, by contrast, many of the features of written expression are shared with oral expression. In such circumstances, crossing from oral to written and from written to oral is easy and frequent, and one may ask how far the opposition which can be drawn between these two modes of expression is not in the end very secondary. Rather, one may ask whether what really matters is the existence, above all, of "genres," of which some are principally transmitted in written form, others principally in oral form, and others again just as well in one form as in the other. The consequences of transmission in these different forms are perhaps no more than some stylistic changes of quite limited scope. In any case, nothing resembles the vast contrast evident in, for example, the European world between, on the one hand, great written literature as we have come to know in the textbooks, and whose development we follow in special newspaper columns or on television, and on the other hand, what has now come to be called oral literature.

\section{BUGIS WRITTEN EXPRESSION}

\section{The Origins and Development of Bugis Writing}

The Bugis possess, together with their Makasar and Mandar neighbours, a syllabic script clearly related to the scripts also found in Sumatra among the Batak, the Rejang and the Malays of the Palembang area, in various parts of the Lesser Sunda Islands, and once too in the Philippines as far north as Manila. L-C Damais has shown their common origin in South India, ${ }^{7}$ but we still do not understand the process of their introduction, spread and derivation from each other. A Makasar tradition attributes the invention of the scripts in use in South Sulawesi to a certain Daéng Pammaté, a syahbandar or harbour master active during the reign of Gowa's ninth ruler, Daéng Matanré Tumapa'risi' Kalonna (c. 1511-1548). ${ }^{8}$ We should definitely reject the idea of invention from scratch, that is ex nihilo, and the relevant period seems too late, even for a simple introduction from outside. In the Bugis epic cycle of La Galigo, which certainly relates to a period earlier than the 12th century at the latest, there are quite frequent cases of heroes exchanging "golden letters" (sure' ulaweng). ${ }^{9}$ Is this an anachronism? Perhaps, but the text itself seems to have taken essentially its modern form somewhat before the 16th century. If Daéng Pammaté must be credited with something, it could be a modification of the characters, since there was 
another syllabic system that was once in use, but has long been abandoned and which could have preceded the modern script. According to a tradition - an oral one - that system in its turn could have been preceded by a third writing system, but as far as I know, no specimen of this survives. Whatever the case, no Bugis documents available to us are very old. Nor do we have from the past any inscription on stone or metal, as in Java, Bali or Sumatra. The earliest texts were undoubtedly inscribed on palm leaves, strips of the leaves of Borassus flabellifer (L.) or Corypha gebanga (B1.); these were then sewn together end to end, and rolled up to form flat cylinders. Only very rare examples of these survive: some in the Jakarta museum, some in the Tolotang community at Amparita and possibly elsewhere. Their age has not been determined. Quite certainly, however, the current Bugis word "to write" is maruki'. This derives from a root with the primary meaning of "engrave," while every manuscript written in the traditional characters is termed lôntara', derived from the Malay and Javanese word lontar, meaning palm leaf. The word comes from a metathesis of rontal, for ron (leaf) and tal (Borassus or sugar palm); the Bugis equivalent would be raung ta'. Hence the original sense of lontara' has been forgotten when applied to manuscripts on paper. Up till the 1920s, these were still written with a traditional pen (kallang), that is a reed cut at an angle and dipped in a locally-made ink. The use of paper seems to have been widespread at an early period, but there again, we have no exact dates. $^{10}$

Bugis texts have been printed from the second half of the 19th century. The first fonts cast seem to have been those intended for the publication of dictionaries, grammars, chrestomathies and Bible translations, both Bugis and Makasar, by the Dutch linguist, Matthes. ${ }^{11}$ The distribution in South Sulawesi of these works, however, seems to have been very limited. Up until World War II, government publishers regularly issued works in Bugis for school use, but the number of pupils at that time was still extremely small and the print runs would have been very restricted. It is almost impossible to find any copy at all of them in the field and the only place I have been able to view them is the library of the Koninklijk Instituut voor Taal-, Land- en Volkenkunde (Royal Netherlands Institute of Southeast Asian and Caribbean Studies) at Leiden in the Netherlands. In South Sulawesi, and unlike what happened in Java, no local publishing industry developed, nor was there a vernacular press, even though very occasionally some small brochures or books appeared. They resulted from isolated initiatives, lacking follow up, and anyway enjoyed only a very poor circulation. A small exception may possibly be found in the stencilled religious booklets put out by the As'adiyah Foundation from Singkang. This 
foundation has also published for some time and in the same format a small monthly bulletin which uses the Bugis language for propagating Islam.

Overall then, for the Bugis, "writing" retains the sense of "manuscript." This applies both to private correspondence (though in this case Bugis is being increasingly replaced by Indonesian, the national language) and to the texts of any age which families pass down from generation to generation and which eventually need to be copied (or recently, even photocopied).

Moreover, we should not imagine these volumes to be carefully placed on library shelves. Leaving aside a few texts regarded as specially sacred, and thus objects of particular attention, the volumes are most often found piled up in confusion on the bottom of an old cupboard, in a box under a covering of areca nuts, or in some attic corner, and frequently in a very sad state of repair with pages missing or torn, mouldy paper and faded ink. This failure to care for the volumes does not mean that their content is not accorded great worth; here again we need to watch that we do not give way to hasty judgements arising from unconscious ethnocentrism.

\section{The Corpus of Writing}

Even before the arrival of Matthes in South Sulawesi, some Bugis manuscripts had been collected or copied for Europeans with an interest in oriental antiquities. Matthes himself and the Dutch scholars who followed him have continued this work with the result that important collections have been built up in Europe, principally in the Netherlands. In Sulawesi itself, the Matthes Foundation in Makassar (Yayasan Kebudayaan Sulawesi Selatan dan Tenggara) has undertaken a similar task and offers its collection - unhappily rather limited - to local scholars. Up till now, only two partial catalogues of these collections have been published. The first, already more than a century old, is a report drawn up by Matthes on the Bugis manuscripts kept in Europe in $1875{ }^{12}$ it urgently needs up-dating.

The second is restricted to the texts belonging to the La Galigo cycle which were held in Europe in 1939. In 1954, the texts of the same cycle held in the Matthes Foundation in Makassar were added. ${ }^{13}$ In addition, Matthes has provided a Bugis Chrestomathie in two volumes, with another volume of notes. ${ }^{14}$ Taken together, these are the only resources available at present to enable us to get an overall view of Bugis writing. Such a view is needed if one is to describe in detail certain private collections to which one has access. The extent of these is usually much more restricted. Some time ago, Hasanuddin University undertook to make a list of these private collections, but the project has not advanced beyond the planning stage. ${ }^{15}$ 
The Bugis themselves usually divide Bugis manuscripts into two categories: sure' and lôntara'.

The word sure', that is writings in the most direct sense-when used without qualification and in relation to a manuscript - always connotes in fact the sure' Galigo, that is sections of this epic cycle. All other writings are described, as a whole, by the term lontara', even if the word sure' appears in their title. For example, manuscripts entitled Sure' attoriolonna toBoné (Writing on the history of the people of Boné) or Sure' pangngaja'na nabitta Muhamma' (Writing on the teachings of our prophet Muhammad) are still, for the Bugis, categorised as lôntara'. There is a further contrast between these two kinds of writing. Lôntara' often occur as a jumble of very diverse kinds of text, following each other in no apparent order and with no clear separation from each other. There are historical chronicles, juridical works, religious treatises, practical information, agricultural and divinatory almanacs, stories, poetry, magical formulas, medical recipes, log-books, etc. Blank pages or the inside of the covers often provide space for accounts or noting down what are seen as important dates, such as the birth of a child, the death of a grandparent or some matter one wants to remember. For example, my good friend Mahmud Nuhung of Sinjai has noted in the margin of his copy of a chronicle of the rulership of Lamatti and Bulo-bulo that on a certain day "Dr. Pelras received the Bugis name of La Massarasa Daéng Palipu."

It is quite a different matter for manuscripts containing sections of the La Galigo cycle, even if their often tattered appearance in no way distinguishes them externally from ordinary lontara'. These texts are never jumbled up with other kinds of text. In fact, these texts tell the story of the first generations of people having a divine origin and before their return to the divine realms. Formerly such manuscripts were not opened without some ceremony and the burning of incense.

What matters for the Bugis, therefore, is the separation between sacred writings and profane writings and not, as with us, that between literary and non-literary writings. The oddly mixed contents of the lontara' clearly show that the Bugis do not set up any hierarchy based on aesthetic considerations in relation to profane texts. Bugis anthologies or commonplace books are built up on the basis of an interest in the content of the pieces, not on the basis of the compilers' appreciation of the way in which this content is expressed. Although there are Bugis manuals on building houses or boats, on medicinal plants, on human physiognomy, on etiquette, on justice and on government, it seems to me quite significant that, to my knowledge, there are no guides to the rules of good writing. 
There is not then any imaginary honour board of great works, middling works and minor works, as in our literatures. If, nevertheless, certain Bugis writings enjoy an undisputed prestige, this derives from nonliterary grounds: La Galigo because of its sacredness; La Toa, or The Elder, because this text, of which there are different versions, has served down the centuries as a guide for the conduct of society as a whole; the chronicle of Boné, which is also available as several different texts, because this principality has played a pre-eminent role in Bugis history. ${ }^{16}$ Neither the process of education nor the presence of a literary class, however, has created a "classical" tradition out of the written materials, in the sense in which I defined "classical" at the outset.

\section{Composition and Reproduction}

There does not seem to have been a class of writers or poets in traditional Bugis society, comparable with the Javanese pujangga. The La Toa, which lists all sorts of functions represented in the entourage of princes, has no mention of such people. As for the manuscript specialists, palôntara', it is the case that they are found in aristocratic contexts and in the rulers' entourages, but there are also some who are simple peasants or performing other tasks. In no instance can one speak of them as a distinct social category.

The palôntara' is essentially someone associated with manuscripts. He owns some of his own and of these he knows the content in detail and instructs those who come to consult him. According to the case, this may involve details of local history, the precise words of certain basic texts, such as treaties and government agreements, genealogical information, and indications of the best times for agricultural activities. Each palôntara' has his specialities as determined by the texts which he holds and he often looks to perfect the texts by borrowing other manuscripts of interest to him from other palôntara' in order to copy them in whole or in part. The up-shot of this then are the "pot-pourris" which Bugis manuscripts so often resemble. Sometimes the exercise is more complicated. For example, a palôntara' who has brought together several incomplete versions of a district's history will seek to draw from them a more complete history. He might also compose on his own account a complementary text, adding in as well what he has gathered from the oral tradition or covering the more recent past if the historical text at his disposal stops at a certain date. He may also keep a diary of events he witnesses. Acting at one and the same time as scholar, copyist, compiler and author, he assigns no ranking to these different tasks, and he will not even dream of signing, as his own work, what he has written 
himself. If one comes across any names in the manuscripts, they are instead those of the copyists, or of individuals whose (oral) maxims are referred to. The rare Bugis texts which can be attributed to a specific author are exceedingly few: several diaries and some religious works among those that are believed to have been composed by Shekh Yusuf, an influential teacher in the 17th century. In general, however, there is absolutely no interest in the personality of the author, even in the case of major works which have obviously come from the hand of an individual master.

\section{The Text}

From the above, it is very clear that a Bugis lontara' is a tangible reality. If it belongs to anyone, it is the owner of the manuscript and he can treat it as he likes. The idea that there could be anything wrong with plagiarism never enters anyone's mind. ${ }^{17}$ So much for simplifying the job of anyone trying to produce a critical edition of a particular text.

In contrast with the lôntara', the sure' Galigo are accorded remarkable respect in regard to their text. If it should happen that anything is changed in the copy, it is the result of a mistake in reading or failing to understand the meaning of an archaic expression which has become unintelligible. I know of no case of deliberate addition or modification. For each episode, however, there are often several parallel versions. These generally contain the same chronology of events - there are variants, but they are rare-and the same characters relating to each other in the same way, but the narrative is told differently. It is still not clear how these different versions have come into existence without upsetting the coherence of the whole enormous structure. Even counting only one of the parallel texts for each episode where there are several and linking them end to end, the total amounts to more than 6,000 folio pages. ${ }^{18}$ The drama encompasses hundreds of characters over six generations and linked with some thirty "kingdoms." Such is the overall coherence that it is possible to draw up a genealogical table for the whole in which each protagonist can find his place. There are very few cases of doubt. ${ }^{19}$ The complexity makes it hard to imagine that the material was created progressively and that the final plot was the work of a series of independent composers. The existence of several treatments of the same episode, however, seems to demonstrate that the texts have had several authors who have, nevertheless, maintained a remarkable stylistic consistency. Whatever the case may be, no author has identified himself, nor has oral tradition preserved any memory of authorship. Tradition attributes the whole creation of the material to La Galigo himself, the son of Sawerrigading, the semi-divine hero of the cycle. The only thing 
which is certain then is that since an early date the texts as given have not been susceptible to changes - unlike the lontara' texts - and that no-one has tried to write new versions of already established episodes or to create new episodes. Since modern-day Bugis consider the events described in the surviving texts to be historical, the events are thus not open to being changed. $^{20}$

\section{The Dissemination of Texts and Access to Them}

The public for written Bugis texts falls into two categories. The more limited is that of the experts, palontara' and passure'. For the former, the manuscripts act as works of reference and they often have the content of the manuscript at their fingertips. If they should happen occasionally to read a manuscript right through, the reason is to get to know a volume which they have borrowed. This generally arises because they have an interest in some point of detail in the volume and they wish eventually to take a copy of this. Other manuscripts, dealing with ritual formulas or poetic texts, provide a sort of aide-memoire or crutch to the memory to which one can refer in cases of serious forgetfulness or mental blank. The passure' experts work quite differently. Their expertise lies, essentially, in the La Galigo texts and, most importantly, they know how to chant these. They display their skill to the public at festivals that bring together a greater or smaller crowd such as a wedding, the setting up of a new house, or the commemoration of the death of Hassan and Hussein on the tenth day of Muharram.

The second category of public for the texts is the population at large, who only have access to the texts by means of the experts already described. This applies equally to those people who have inherited manuscripts from their forebears, but are not themselves experts. Such people can, for example, on the occasion of some ceremony, call in a passure' and get him to read in public a La Galigo text which they own. It seems likely that palôntara' once provided the same service for lords and princes who held historical or customary law texts, and possibly they might even have read out the written versions of certain fictional narratives. Another way for the population at large to gain access to these texts is through consulting one or more experts. Thus, at the beginning of the agricultural year, local authorities are in the habit of bringing together for discussion (tudang sipulung) the palôntara' who own manuscripts dealing with agriculture. The purpose of the meeting is to fix the dates for beginning various tasks - the first ploughing, the first sowing, the first harvest - in accordance with the information provided by the manuscripts on the progress of seasons, predictions of wind and rain, and auspicious and inauspicious days. 
The role of the experts then is to ensure the dissemination of the written word and they do not do a bad job of it. In the course of my stay in Wajo' in 1967-1968, I was able to ascertain that many people had a relatively extensive and detailed knowledge of the La Galigo cycle without ever having had direct access to the texts. They had acquired this knowledge just by having heard the texts read, or even by just having heard a summary of the story, which could thus reach them through several intermediate stages. Moreover, in the same way, the passure' experts got to know episodes which they did not themselves have to hand; this is in reality the major part of the cycle. Nowhere is there a complete collection of the episodes.

As for the information in the lontara', knowledge of that extends among more limited circles in a more or less vague halo. If one needs precise detail, it is necessary to have recourse to the manuscript, but if this is not available-because it has been destroyed, lost, lent or is kept elsewhere - the knowledge of this small group of knowledgeable people can also be a source of reference. In this way, I have been able to collect much historical data relating to small local communities where the documents were no longer available. ${ }^{21}$

It is perhaps this individual relationship with writing which explains why local publication has never developed in South Sulawesi, although this would have been technically possible from the end of the 19th century. The Bugis public are not readers, but listeners. The same attitude applies in relation to literature in the national language. There are authors in Makassar who express themselves in Indonesian, but their stories and poems are published in local newspapers and reach only a very limited audience. Several attempts to establish literary or cultural reviews have run out of steam after a couple of issues. Books occasionally put out by local presses have very limited print-runs. Public readings of poetry, however, organised by the Makassar Arts Council, attract a large audience of locals, as do competitions between young drama groups. 


\section{BUGIS ORAL EXPRESSION}

\section{Conventional Genres}

For the moment, I take "conventional genres of oral expression" to mean all speech other than the purely utilitarian (that is, conversation, calling out, giving orders or any spontaneous expression of thought or feeling). There must be no recourse to any form of writing and the expressions must be subject to certain formal requirements that allow the expressions to be grouped into various categories. Some genres are characterised by a more or less fixed text and one is supposed to recite the material word for word as learnt. The Bugis have, in this category, precepts (pappaseng), playful sayings such as riddles (atteppungeng) and nursery rhymes, magical spells (jappi, baca-baca), pre-Islamic ritual expressions (sabo, sessukeng, lawolo), oaths of allegiance (aru), various types of short poems (élong) that are always sung like our Western songs, and long narrative poems (tolo') which are chanted. Among the genres of a more relaxed character, the most important are stories (curita), sermons (katoba) and speeches (called pidato in Indonesian). Although they are basically oral, it should be noted that most of these genres also occur in written form, with the possible exception of riddles and nursery rhymes, sermons (though they are closely related to many religious writings) and speeches.

\section{Performance and Dissemination}

Each conventional genre of oral expression has its own circumstances for performance and its own "experts." In the case of playful sayings, I have little information; they seem to be equally well-known among the various groups in society. The precepts which are often, but not necessarily, attributed to great names from history are readily recited by those who enjoy some degree of moral authority. Until recently, these precepts would have been one of the favoured methods of passing on and giving instruction in the essential values of society. This process can still be seen in the Kajang community who use the Konjo language which is close to Bugis. ${ }^{22}$ Precepts are also still used quite often in wedding speeches. Magical spells, of course, are known to a more limited circle, but this is not restricted to sanro (traditional healers). Many ordinary individuals know them and put them to use in various situations in the course of the major events of their life or in various undertakings. In fact, one is here at the extreme edge of orality since these spells are always recited to oneself; they are only spoken aloud at the time of passing them on and often this only happens once in a lifetime when 
an elderly person decides to teach them to the man or woman selected to inherit them. It is not easy, I suppose, to inquire about such matters in conversation, ${ }^{23}$ but examples of these spells can be found in a few manuscripts. Some stories also contain instances of spells.

As for what I have called "pre-Islamic ritual expressions," I mean chiefly the long formulas recited, chanted or sung in a high voice by the bissu, the survivors of a pagan priesthood which was formerly associated very closely with the royal courts. Recent developments in the Bugis world have restricted them to a residual role, and even if they do take part in certain ceremonies, it is with an abbreviated ritual which has been shorn, among other things, of its ancient oral content. Surviving bissu, however, always know these texts and Gilbert Hamonic has been able to collect very many of them. He is currently busy translating them, which is difficult since the texts are in an archaic and obscure language and the bissu themselves cannot always supply exact meanings. ${ }^{24}$

Another conventional genre which is now little used is the swearing of allegiance $(a r u)$. This was formerly the practice of noble warriors who, one by one, with drawn sword or kris and in full armour, performed a rhythmic dance in front of their lord, either at his enthronement or before battle, in order to reassert their allegiance to him. This is now only performed in historical re-enactments, but the formulas seem to be still quite widely known in aristocratic circles, above all, of course, among men of a certain age.

The case is quite different, however, with oral poetry, which is very much alive. The most widespread form of traditional Bugis poetry is the élong that consists of a three-line verse (or more rarely a four-line quatrain). The lines are normally of decreasing length. A standard élong has three lines of eight, seven and six syllables. Each three- or four-line verse makes sense within itself, but is readily linked to others either by simple juxtaposition, or by analogy, or by taking up a word in the previous verse, or in a series of alternating responses. This poetry is not spoken, but sung; the root élong also produces, with an affix, makkélong which means "to sing." There are different kinds of élong depending on the subject; some belong in particular categories or to particular situations. Thus, there are élong ana'-ana' (children's songs) like nursery rhymes; élong padondo' ana' (lullabies); élong maddakkala (plowing songs); élong éja'-éja' (songs for young couples); élong osong (war songs); élong massagala or élong maccamané (praise songs to conciliate the spirit of smallpox during an official epidemic.) The three last types are not much used. The same applies to the practice of swapping verses, sometimes in a courteous way (élong sissengngisseng), sometimes a little sharply (élong mapparéré), between men and 
women at weddings, although the words of these exchanges continue to be known and sung by amateurs who sometimes shift between the male and female parts in turn. Other élong are sung without regard to the particular circumstances and evoke the sad fate of orphans or exiles (élong toto') or the joys and pains of love (élong tomalolo'), or they happily set out a joke which often descends to nonsense (élong mappadicawa), or again they pass on religious injunctions (élong topanrita) or traditional wisdom (élong pangngaja'). ${ }^{25}$ Familiarity with this sung poetry and its performance appear to be almost equally spread among all groups in the population, including the youth. Schooling seems just to add to its popularity. Naturally, certain amateur performers have a particularly extensive repertoire and this also applies of course to the professional or quasi-professional musicians (violinists and players of the lute or kacapi) of whom there are very many among the Bugis.

A quite special case is that of the modern Bugis song which has become increasingly popular in recent years. It has been supported, in the first place, by western-style orchestras (wind instruments, guitars, drums, perhaps an electric organ and sound system). Such orchestras may be hired for weddings and some, such as Irama Sawitto or Sirar Wajo', have become well-known throughout the whole province. The music is derived not so much from Western models as from the music of Malaysia and India (under the influence of Bollywood musicals). On this basis, the orchestras have created a fashion for a kind of modern-style song, generally consisting of a succession of quatrains with lines of equal length. Their themes, inspiration, style and expression, however, draw much from traditional models. These hits are now recorded on cassettes and reach the most remote corners of the region thanks to the spread of portable cassette players and transistor radios. Certain performers have become very popular and some have achieved national recognition.

Cassette recordings have also provided a remarkable means of dissemination for professional or quasi-professional musicians whose repertoire consists chiefly of sung stories - tales or narratives (curita). These compositions are in rhythmic form, based on a line of eight syllables, but keeping close to the spoken language. It used to be normal, on the occasion of certain domestic celebrations, to invite these performers into a home and to pay them for an evening's playing. With the growth in the number of cassette players (which first appeared in South Sulawesi in late 1968) there was at first some dislike of the cassettes. This was reinforced when many people recorded the songs during one of their parties and immediately distributed the recordings. This got around the need to have the performers present in person and to pay them. The response from a number 
of performers was not long in coming; in collaboration with shrewd businessmen in Parepare, Singkang and Makassar, they undertook the recording of their own cassettes, which are now available in all the radio shops and distributed in every market across the province. Some performers have thus extended their reputation into a much wider sphere than previously. A number of the cassettes, however, remain anonymous.

These sung stories with kacapi or violin accompaniment display some relationship with the traditional chants (tolo'). These traditional chants too were long stories in eight syllable lines and were above all epic in character. They were, however, composed in a style which was often more difficult and old-fashioned and their text, unlike that of the sung stories, was fixed. These tolo' seem no longer to be chanted, unlike their Makasar equivalents, the sinrili'. The only tolo' I know of are in written form, although without any shade of doubt, what one has here are texts intended for oral performance. $^{26}$

Other stories, also called curita (or rather pau-pau in the past), are recounted in a quite straightforward way by storytellers. These people are never professionals, even if some of them achieve a wide reputation. There are no special conditions for telling or hearing these stories; it is enough for both tellers and hearers to have the time and that one is happy to agree to the request of the other. The storytellers' repertoire consists chiefly of rather long stories, usually taking between one and three hours. I have even heard of one - the story of Iskander, that is Alexander the Great, which is also well-known to the Malays - which takes several evenings to tell in full. There is no lack among the Bugis of clever storytellers, nor is there shortage of time to hear them, and their repertoire is vast. An adult Bugis, therefore, would certainly have heard, on average, many more stories than a Frenchman of the same age would have read novels.

As for the last two genres, sermons and speeches, they are similar and deserve a special study since they are important means of transferring ancient values and of spreading new values. Their impact on Bugis society should not be ignored. It is well-known that, in Indonesia, the Bugis have a reputation as very observant Muslims. Even if this image is a little superficial, it is true that religious scholars enjoy great prestige among them. In addition to the sermons at the Friday gathering, Bugis listen very willingly to those which are broadcast each morning on private radios and crowds attend those sometimes given during Ramadan or at Qur'an reading competitions. At weddings, well-known scholars are also invited to come to the family home and display their learning to the guests. These sermons are always in Bugis, with of course the proper mix of Qur'anic quotations in Arabic. On the same occasions, notable relatives may also be invited to 
deliver non-religious speeches and such speeches are often laced with old precepts, as well as phrases in Indonesian. A certain measure of bilingualism can also be seen in the speeches delivered at all levels of government and at all kinds of civil and civic functions.

\section{Text and Composition}

I have grouped above the various conventional genres of oral expression into two categories. The first is characterised by the existence of more or less fixed texts. A performer is supposed to recite the words exactly as he has learnt them. The degree to which the text is fixed, however, can vary in different cases. Nothing prevents children from amusing themselves by changing a nursery rhyme. By contrast, a magical spell is thought to be only as powerful as the extent to which it is delivered exactly. Some changes, though, can be made to the spells in well-defined situations specifically to increase their efficacy; for instance, "revelation" may be claimed. In the case of the bissu formulas, Gilbert Hamonic's collection of numerous versions of the same text demonstrates that the text forms only a basic canvas on which embroidery is always possible. ${ }^{27}$ Moreover, the occurrence of changes is made easier by the obscurity of the text. This may lead to a word which has become incomprehensible being replaced by another with more or less the same sound. Similar instances can be found in the copying of old manuscripts. ${ }^{28}$ Despite this flexibility, no-one imagines that new bissu formulas can be composed, for the formulas are thought to be a heritage from the beginning of time. It is even inconceivable that they can have had authors. The same applies with simple magical spells, for it commonly happens that someone will declare that he has not inherited one or more spells that he uses from someone else, but that they have been revealed to him in a dream. It follows that the beneficiary of such revelation does not at all think of himself as the author of the spell. He gives the credit for that to the "invisible being" (totenrita) from whom he has received the spell. Although these texts are kept as secret as possible and thus the stock of them turns over slowly, it should be noted that those which one can none the less find out about seem to obey well determined patterns.

In the field of sung poetry, the fixity of the text is less assured. For example, the linkages of élong are more or less free, with the exception of some very well-known progressions, such as the famous songs Bulu' alau'na Témpé (Hill to the east of Témpé), Indo' Logo (Mother Logo), or Ongkona Arung Mponé (The privilege of the ruler of Boné). Yet even these cases can display different sequences once beyond the first three or four verses. 
Likewise, in checking one three- or four-line verse against another, lines are often seen to be substituted, and in checking one line against another, certain words are substituted. In a way, one is dealing with a verbal Meccano where each performer is responsible for putting together his own work. In these circumstances, composition can be regarded as an on-going process; one recognises that the concept of composer does not exist, while at the same time acknowledging that certain performers have had or might still have an important creative role. This creative role, however, is only one aspect of what they do and no more highly regarded than other aspects. Bugis has no word for "poet"; pakkélong can only be translated as "singer."

A new attitude has appeared with the modern Bugis song. The names of both performers and composers are given on the cassette tapes. Nonetheless, many of these composers seem to have had recourse, at least in part, to former ways. I recall reading in 1979 an indignant letter in Pedoman Rakyat, the local newspaper. The writer complained of having found on a cassette the full and exact text of a song he had composed two or three years before, but with another title and under the name of another composer. I would not guarantee either that the letter writer's text was 100 percent original! The substitution of verses and lines is in fact still common, even if it is more limited. It is not impossible, however, that little by little the position of original composer/poet might emerge among the Bugis, a hitherto undescribed role. The presence of Bugis poets writing in Indonesian should play a determining influence here.

That there were once true Bugis poets is, however, certain; the tolo' and other texts of similar construction show without doubt all the signs of an individual poetic imagination. In these cases there is no substitution; the writing is original and the language individual. No one knows the names, though, of those who composed these poems, any more that we know who were the authors of the great written texts. ${ }^{29}$

With genres of a more spontaneous kind, things are different because one is looking for the individual or original touch which the performer of a sung story, or a storyteller, or an orator will bring. In these cases, the performer is also, at the same time and by definition, a creative composereven when he is repeating for the umpteenth time the same story or the same speech, one can look for the difference in the way he formulates it. The notion of "text" is inappropriate then and ethnologists or linguists who collect it should not forget that the sound recording or written record that they possess does not give the text of a story, nor the version of a storyteller, but merely one of his performances. Despite the ephemeral nature of their compositions, these are the creative composers who are without doubt the 
closest to our writers; they have a close individual relationship which ties them to their works.

\section{RELATIONSHIPS BETWEEN BUGIS WRITTEN EXPRESSION AND BUGIS ORAL EXPRESSION}

As, I trust, the reader will now be aware, the Bugis do not have a written literature and an oral literature which are distinct and clearly contrasted. ${ }^{30}$ Rather, there are genres, many of which can just as well exist in written as in oral form and, in the latter case, with a text that may be fixed or free. For certain genres or for certain themes in a given genre, some ways of treating material are preferred-written expression or oral composition, with fixed or free text-with the result that at the extreme certain genres or themes only occur in one of these forms. The criteria, however, which cause a particular mode of expression to be preferred are not literary in the sense we normally understand by that term. They relate to the nature of the utterance and to the question of knowing whether writing or orality, fixed expression or free expression, are or are not appropriate to its uttering, to its conservation, to its transmission, to its dissemination and to its comprehension.

Oral utterance normally assumes the presence of listeners, whereas written utterance is a solitary activity. A reader only becomes aware of the written utterance after the event and this reader may even be the author himself. Writing is thus better suited to the creation of texts involving reflection or to making a record of private notes. Orality, on the other hand, allows a much greater flexibility of expression and demands a public. Even magic spells recited to oneself or just brought to mind presuppose the presence of an invisible audience.

Similarly, the conservation and transmission of the utterance are dealt with in different ways by writing and orality. A written text may, in itself, last for a very long time and its longevity does not depend on that of the manuscript's owners. A manuscript might very well be forgotten for generations, only to be one day rediscovered by chance. Manuscripts are not, however, immune to various dangers. Their fabric is always perishable; they can be destroyed by fire, damaged by water, eaten by insects, they can be torn or lost pages. In the case of total loss, it may be that the text itself is also lost irredeemably. If the destruction is only in part, the surviving pieces may still be mere fragments. These risks can be lessened by making copies, though these should be full and careful copies.

By contrast, an oral utterance is, by its very nature, ephemeral. The wish to make it endure is, if one thinks about the matter, a long shot. The 
reality is, though, that this can come off and human memory can sometimes measure up to that other form of memory which written texts provide. In this case, the two kinds of oral utterance need to be distinguished: free utterance where what matters is keeping the content of the message and fixed utterance where the actual words themselves tend to be maintained. In practice, of course, the contrast between the two is not always so marked. For example, a storyteller tends to employ more or less the same words to tell the same story; on the other hand, in the recitation of a text with fixed wording, there is always substantial possibility of introducing deliberate or accidental change. Whatever the case, the human lifespan cannot match that of manuscripts and oral utterances can only be conserved by being retransmitted to each new generation. The process of apprenticeship, though, is less reliable that of copying, above all when it is a question of long and difficult utterances and even if the presence of set words provides valuable help. It may also be that the owner of an oral tradition is not able or does not want to pass it on, or there may be no one able or willing to receive it. This is the case with the bissu, whose knowledge is currently being lost due to the lack of enough young followers. This is caused by the almost complete loss of their ancient roles in society and their failure to perform many of their old ceremonies. ${ }^{31}$

Writing, then, better suits the conservation of precise information, historical data, dates and long works, especially those with archaic or difficult language, though in such cases a parallel oral tradition is very useful for providing interpretation. Orality is well suited to telling materials in which the content is more important than the exact words and details, or to short and easy formulas and texts, such as magic spells, for which one wants to control transmission. Very long texts with a set form, which in other cultures are committed to memory, tend to be established in written form just as soon as the means to do so exists. ${ }^{32}$ Orality is clearly the most effective means of expression when it is a matter of spreading the substance of a message in the absence of a mechanical means, such as printing, for producing and copying the written word and when, moreover, a good part of the population cannot read. Orality allows one to reach quite a lot of people at the same time, while writing only reaches readers one by one. Moreover, the owners of manuscripts do not like to hand them around much for fear of losing them. Public reading of written texts allows one to combine the advantages of both means of expression, but this procedure, just like reciting fixed formulas, does not do much to help full understanding of the text, especially when the text uses language which is no longer well understood today. For good understanding, both individual reading, which allows one to 
reflect or to consult an expert on specific matters, and free oral expression, which falls back on instantly understandable language, are more effective.

Thus, each has its own advantages and inconveniences-whether writing read by a single person or read out in public, or orality with a fixed text or with free expression. It is these advantages and disadvantages which lead Bugis to choose to express themselves in writing or orally according to the genre of the utterance.

For example, the episodes of the La Galigo cycle only exist in writing, but they need oral support because they are performed orally and their place in the overall scheme of the cycle can only be appreciated by the oral dissemination of other episodes. In these public performances, the texts are not simply read aloud, but they are usually chanted in a way called massure' selléang (that is, to read the sure' with variations) according to a specific kind of tune in which several verses are strung together as one breathing unit. In the past, they were chanted in a non-melodic way called massure' toriolo (that is to read the sure' in the ancestral way) like the recto tono of Catholic monks in which tonic accents are well marked and each verse is clearly distinct from another. Although listeners enjoy massure' selléang very much, this kind of performance makes it difficult to catch the words. The language of these episodes is, moreover, extremely difficult and they can only be understood as a result of prior knowledge and the commentaries which are given on them. Besides, one might ask whether these texts were not, in the beginning, completely oral. The arguments for this hypothesis are the five-syllable rhythm, which sometimes has to become four-syllable when the stress (marked by a circumflex in the example below) shifts from the second last to the last syllable, and the frequent use of "plugs" with no meaning (lé) or very little (ronnang). ${ }^{33}$

Kûa adânna

to Palanrô-é:|

"Appangâra-o,|

Sangkabatâra|

narileggâreng

calikerrâ'na

lé lângi'-ế|

lé narirêddu'

t'éma gonrâtung|

lé pasulûna

tânge' batâra

rakîle'-^é,|

risênné dûa 


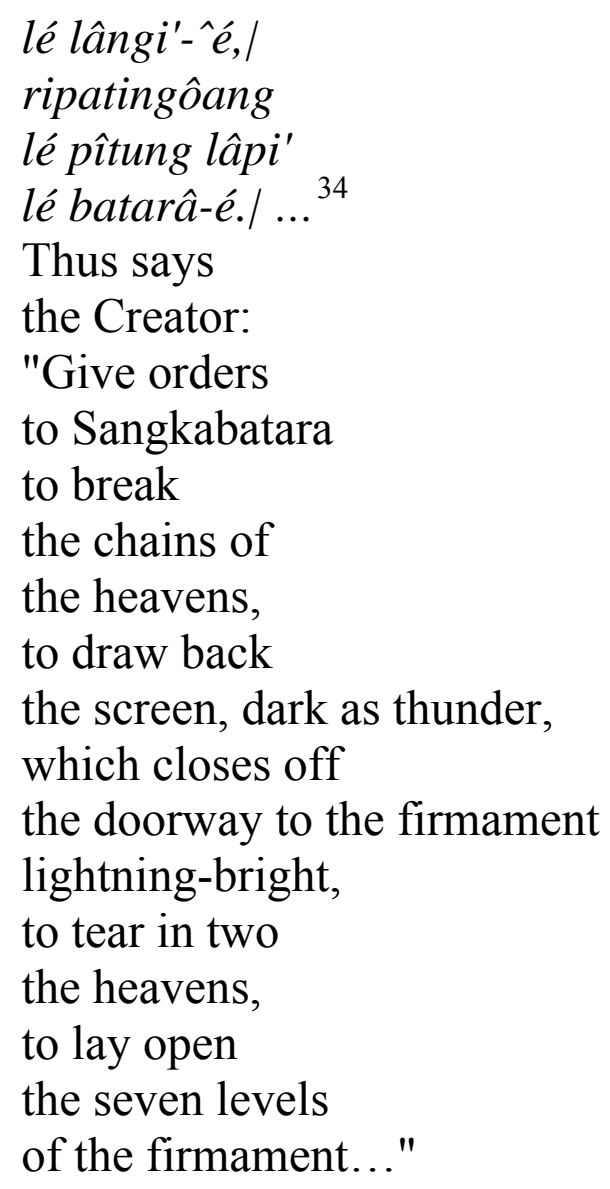

Given the extraordinary dimensions of this immense epic, it may be easily realised how the text's conservation was better assured by writing than by orality, but the epic could not have attained the fame which it has if knowledge of it had been kept to individual readers alone.

On the other hand, it is not surprising that Bugis manuscripts contain relatively few narratives or tales - or to put it the other way, that a small proportion of narratives and tales occur in manuscript form. Matthes' catalogue lists only a score from a total of 109 Bugis manuscripts indexed; in Sulawesi I have only seen two myself. The nature of the themes found in the written versions, and of those only found in oral versions, is particularly noteworthy. Most manuscript stories are actually linked to Muslim tradition: the story of the prophets, episodes in the lives of Muhammad, of Amir Hamzah, of Ali and Fatimah, of Hassan and Hussein, and of Muhammad Ali Hanafiyah, narratives of the dirty tricks and wise acts of Abu Nawas, and also the Alexander romance. ${ }^{35}$ These stories appear to be inspired by Malay models, themselves influenced by Persian exemplars. I have oral versions of several of them and no doubt oral versions could be found for them all.

Other stories, with more profane themes and of which at the moment I only know written versions, in the same way contain themes also met with 
in written Malay literature, though it is not just a matter of pure and simple translation from the Malay. Still others, which seem to exist only in oral versions, clearly display Malay inspiration, though it is not possible to set out in detail whether they were spread by written or oral means, or by whom, or by what stages. One example, among others, is that of the comic stories which concern the pulando', the mouse deer-pelanduk in Malayan animal which is no more to be found in South Sulawesi than the tiger, one of its regular foes. ${ }^{36}$ The existence of a Malay colony in the Makassar area, attested to since the end of the 15th century, is doubtless not unrelated to this. ${ }^{37}$

There are only oral versions of the great bulk of the stories that I have been able to collect, whether they are spoken as free prose narratives or sung as texts with a roughly eight-syllable rhythm, and in which there is no obvious external influence. It is not impossible, though, that a thorough analysis would bring to light some remembered traces of this or that written tradition.

Just as, however, written materials show themselves in oral form in certain cases, it is equally clear that certain written texts originate in oral narratives. That applies not only in their content, but also in their form, even by often using orally-derived phrases. Compare the following examples of written and oral materials:

\section{A - Written}

Engka, engka garé', engka séuwa wettu, engka séuwa arung makkunrai ri Luwu', malasa uli'... ${ }^{38}$

There was, there was they say, there was once, there was a princess of Luwu', a leper...

\section{$1 \mathrm{~B}$ - Oral}

Makkeda-i punnaé corita, engka garé', naengka wettu, naengka makkunrai, matane' wettang... ${ }^{39}$

The holder of the story says, there was they say, there was a time, there was a woman, heavy with child ...

\section{$2 \mathrm{~A}$ - Written}

Bellé ripau, oncong-pisa belléna toriapauangngé; apa', majeppu bellé ripau, nakado-i-maneng-mui... ${ }^{40}$

A lie is told, so much the more is it a lie by those at the telling, for knowing a lie is told, they still all nod their heads in agreement ...

2 B - Oral

Pau-pau rikado-i, iriseng-ni bellé, narikado-i-mupa!... ${ }^{41}$ 
It is a telling which is agreed to by nods, it is known to be a lie, but it is still agreed to by nods ...

\section{A - Written}

Rirakkai adaé, risittaki paué... ${ }^{42}$

The words are hurried, the tale is hastened ...

\section{B - Oral}

Riponcoki coritaé... ${ }^{43}$

The story is shortened ...

Given the extreme rarity in South Sulawesi of manuscripts of free prose tales, I am not quite certain of the means by which the stories were disseminated. This was not, I think, just by individual reading, but the stories must also have been performed in public. In support of this hypothesis of public performance, I have in my possession a commercial cassette - the story, in prose, of I Daramatasiah-which seems to be a chanted rendition of a written text, rather than a performance from memory. There is no musical accompaniment and the chant consists of a spaced succession of phrases at a fixed pitch and pronounced with a very rapid delivery. It resembles readings of the Barasanji, the Arabic story of the prophet Muhammad, which is read during many domestic Muslim ceremonies.

Other texts found only in written versions nonetheless display certain characteristics of orality. This applies, in the first place, to tolo', long poems with eight-syllable lines that I would describe as chants. Their subject matter is above all historical, but occasionally also didactic (Sure' Pangngaja'na Nabitta Muhamma'-Writing on the teachings of our prophet Muhammad) or lyric-symbolic (Sure' baweng-Tale of the parrot ${ }^{44}$; Dararinna baléwé-Lamentation of the fishes). By what means these are disseminated and, if they were read in public, how they were performed, I have still not been able to discover for sure, since it seems that no one does it any more. (That, by the way, demonstrates well one of the advantages of writing; it can preserve texts which would have fallen into oblivion in a purely oral tradition.) These tolo', however, display a clear relationship in their method of creation with certain stories which exist in both written and oral versions, and which employ the same eight-syllable metre, even if their language is generally more simple. These stories have been discussed above and include examples such as La Padoma Ennaja, La Dado', Wé Ané, or the very famous story of Méong palo bolong-ngédé, the Black Cat who guards the rice goddess; one day, because her cat has been mistreated, she decides 
to desert humankind. These texts, whether sung from memory or, if they are written, are chanted to the melody of sure' selléang. Although I have never heard them described as tolo', they are so similar that one can think of both of them taking advantage of the same kind of performances. One has, moreover, only to compare the two examples below to see the similarity in their form.

Ri uleng pébéruari

taung sisebbu arua

ratu'na seppulo dua

lélé-tongeng-ni, la béla!

akoasanna Balandaé

ri to Anggarisi'-édé... ${ }^{45}$

In the month of February

of the year one thousand

eight hundred and twelve

then truly passed, my friend,

the power of the Dutch

to those Englishmen ...

Tekkupauwang-mémeng-go,

tekkubicikeng-mémeng-go,

narékko engka élo'mu

tama rilaleng mpulu'

ala-i sinapammu

olli'-i tau tebbe'mu;

najokka, naseng, ana'ku La Padoma

tennala-i sinapanna,

tennaolli'-i tau tebbe'na... ${ }^{46}$

Have I indeed not said to you,

have I indeed not whispered to you,

if it is your wish

to enter into the hills,

take up your gun

call up your followers;

my son, La Padoma, has gone, he says,

without taking his gun,

without calling up his followers... 
One can find, in the oral texts, some irregularities of metre (the performer fills out the defective lines by lengthening syllables when he is short of them and compressing them when he has too many). Despite these, though, it seems that one is dealing here with the same category of texts. What is, however, difficult to say here is whether the written form precedes the oral, or vice versa.

Although the stories that kacapi players and violinists sing also have a roughly eight-syllable rhythmic structure, they can be quite clearly distinguished from tolo'. Their metre is much less restricting and often disappears to let natural expression of the spoken language take over.

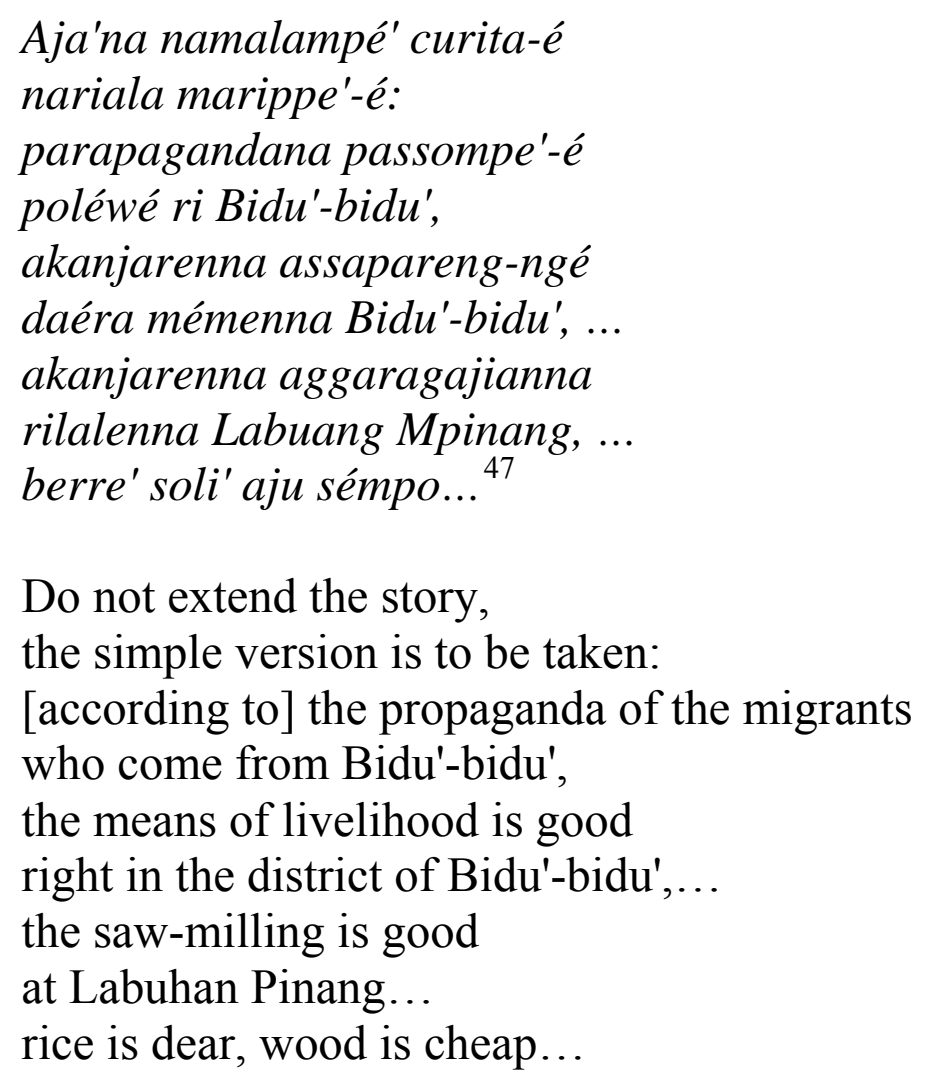

Do not extend the story, the simple version is to be taken:

[according to] the propaganda of the migrants

who come from Bidu'-bidu', the means of livelihood is good

right in the district of Bidu'-bidu',...

the saw-milling is good

at Labuhan Pinang...

rice is dear, wood is cheap...

In the introduction and at the end of sung narratives, one sometimes finds rather general purpose formulas in which the eight-syllable metre is a bit more regular, mainly thanks to using "plugs" with no meaning. For the most part, however, improvisation still plays quite a large role and this explains why there are no written versions of these stories in this form.

As far as the sung poems of the élong type goes, these have fixed texts, even if written versions are rare, and doubtless they can be more easily memorised because of the brevity of their constituent elements and the suppleness with which these can be linked together. A difference should be noted, though, in the ways they are treated orally and in writing. Here, 
for example, are the beginning of a very standard élong sequence (with verses of eight syllable, seven syllable and six syllable lines) in the form in which it is found in a manuscript:

Peddi'-paro ko tobiu: malasa, tenrijampang, maté, tenriwalung.

Riwalung-si, daung loka;

rilemme' gangka uttu'

nasungke'-si bawi.

It is really hard as an orphan:

[when] sick, you are not cared for

[when] dead, you are not wrapped in a shroud.

Even [if you] are wrapped in a shroud, it is a banana leaf; buried to the depth of a knee pigs will dig you up again.

In this written form, these élong can provide the text for chanting which, in Wajo', I have heard referred to as galigo, although the melody used has nothing to do with that used for reading episodes of the La Galigo cycle. They are most commonly performed, however, as sung from memory; the basic text is then given innumerable additions (indicated below by square brackets) and repetitions (indented below):

Peddi'-paro [samanna maié] ko tobiu peddi'-paro [la maié] ko tobiu malasa [samanna-ro] tenrijampang malasa tenrijampang

maté [la] tenriwalung

Riwalung-si [samanna ié] daung loka riwalung-si [palé'-ro] daung loka

rilemme' [palé'] gangka uttu' rilemme' gangka uttu' nasungke'-si bawi ${ }^{48}$

In this example, it is still quite easy to recognise the basic text for the additions are relatively few in number and of little significance (Samanna- 
as it were; maié - this way; -ro-there; ié-yes, or thus; palé-then). This is not always the case, however, and then the regular structure of the underlying élong is rather difficult to bring to light.

Turning back to prose, and more especially to the historical texts, written expression takes the dominant role. Even though the ancient chronicles could occasionally in the past have been chanted to a melody like that of the Barazanji, like other prose texts, there were never, as far as I know, chronicles committed to memory which had a fixed text comparable with the texts in the lôntara'. The lôntara' texts provided much more easily a secure means of recording dates, or rather the time interval between one event and the next, a detailed narrative of events, a record of the terms of treaties and agreements, etc. They were also the best means of guaranteeing precision and objectivity, which are two features the Bugis expect in this type of text. By contrast, tolo' dealing with historical matters are not so much history as poetry about history. There are also oral traditions about the past and these should certainly not be neglected; indeed, they are particularly useful when lôntara' have disappeared or for passing on details which complement the lontara' or for remote periods before the habit of recording events in writing had developed. One knows, however, not to expect the same precision in them and they are even more deficient than the lôntara' in regards to chronology. Nonetheless, the compilers of the written chronicles made use of oral traditions as one kind of source among others; in the same way they borrowed information from the diaries which many rulers once kept, from genealogies, from collections of treaties and from other chronicles. When, however, they incorporated a tradition which seemed to them to gloss over some improbability - among other cases this applies to some legends about the heavenly origins of the first rulers or about the rulers' mysterious disappearance at the point of death-they took good care to bring this out by using the expression garé, "so the story goes."

Some formulas of a markedly oral character are also included in these texts, such as the formulaic wording of treaties between political entities and of agreements between subjects and sovereigns. Moreover, it is not just enough to preserve these in written form; some of them have to be periodically recited, for instance at the enthronement of a new sovereign. Many experts still know them by heart. For example:

Mangolli'-i narisawéki; mattampa-i narilaoi; 
massuro-i naripogau'

ri adécéngenna Tanaé ri Wajo'...

Tudang-ko, lléu-ko, jokka-ko;

munawa-nawa-maja'-ki

ana'-ki', eppo'-ki' to Wajo'é,

maté-o ri tudangemmu

ri léuremmu ri jokka-jokkammu... ${ }^{49}$

He calls and he is come to;

he summons and he is gone to;

he orders and it is made to happen

for the good of the land of Wajo'...

If sitting, lying down, walking

you think ill of us

our children, our grandchildren, the men of Wajo',

you will die on your seat,

in your lying place, in your walking...

The rhythmic structure of these formulas is very perceptible, even if irregular, and the incantatory tone unmistakably reminds one of magic spells which are themselves eminently oral. Observe the following case:

Tubunna I Anu telleng-ngi ri tubukku, atinna I Anu telleng-ngi ri atikku, nyawa I Anu telleng-ngi ri nyawaku, rahasiana I Anu telleng-ngi ri rahasiaku, pappujianna I Anu ri aléku mappada pappujinna nyawaé ri tubué. Barakka', kumpayakung! ${ }^{50}$

May his body sink in my body, may his heart sink in my heart, may his spirit sink in my spirit, may his secret sink in my secret, may his love for me equal the love of the spirit for the body. Blessing, so be it. 
Among the Bugis, then, written expression and oral expression are closely linked and complementary. Movement from one to the other is frequent and unexceptional. Written material incorporates many elements borrowed from orality and oral forms help in disseminating written forms. Oral forms in their turn, however, readily draw on reserves of written materials like a memory which cannot be eroded by forgetfulness.

The selection of one mode of expression rather than the other depends upon what one wants to emphasise about the nature of the utterance and not on a division in principle between genres which are written and genres which are oral. Moreover, writing, which is not in itself nobler or more prestigious that orality, displays many characteristics which elsewhere would be associated with orality. It is this which clearly marks off Bugis writing from written literature such as we are familiar with in our modern world.

It seems to me necessary to distinguish three situations. Firstly, there are societies where the dominant role is held by a great written literature, usually in printed form, and where "oral literature" more or less contrasts with "great literature" of which it becomes a kind of negative image. Secondly, there are societies with no writing and where there is only an oral literature. Thirdly, there is the situation described here in relation to the Bugis, but which more or less applies in other parts of Indonesia such as Sumatra, Java and Bali, in Malaysia, in some other Asian countries and possibly in Europe before the Renaissance. This situation is characterised by manuscript texts, rather than printed ones, and literature is a single entity in which writing and orality are inseparable forms of expression. It would be no more sensible to study written texts as works which could be treated in isolation from the oral tradition, than it would be to concern oneself with oral expression while ignoring all the richness of written materials.

In this third situation described above, however, one can only speak of "literature" in as far as this term is shorn of the entire set of connotations which are only to be associated with written literatures of the first type.

"Bugis literature" is quite simply the whole body of utterances being made within a range of genres determined by rules which are not set out. Above all, it is a linguistic field for which codification is implied.

It is interesting to note that a literature, in the sense in which we understand the term in modern Europe, and with the support of printing, has begun to develop in South Sulawesi; but its language is Indonesian and its public, which is still slight across the province, is limited to the intellectual world of the city. Nonetheless, if this development continues, it could eventually reduce Bugis written expression to a dead tradition, of interest 
only to scholars and men of learning, and downgrade oral expression to folklore, still alive perhaps, but relegated to secondary status.

A Bugis literature which was flourishing, productive and popular would only have a hope of maintaining itself and developing in parallel with literature in the national language insofar as it could take maximum advantage of the modern methods of dissemination which are most appropriate to it, namely the audio-visual methods of cassettes, radio and television.

For, whether in oral or written form, Bugis is made to be heard.

\section{ENDNOTES}

1 The original version appeared as Pelras, Ch., "L'oral et l'écrit dans la tradition Bugis" in Asie du Sud-est et Monde Insulindien (ASEMI) 10 (1979): 271-297. It has been most usefully reprinted, with minor alterations, in Pelras, Ch., Explorations dans l'univers des Bugis: Un choix de trente-trois rencontres (Paris: Cahier d'Archipel 39, 2010): 123-143. Pelras thanked the late Jacques Dournes for his useful comments on a first draft of the article. [Christian Pelras also read a draft of this translation and offered many useful suggestions. In general, the endnotes are derived from the footnotes to the original text, but some later references have been added by Campbell Macknight with the encouragement of the author. This additional material is in square brackets.]

2 [Christian Pelras (1934-2014) was a French ethnologist who worked both in France and in Southeast Asia, primarily in South Sulawesi which he first visited in 1967. He was concerned to document a given society as fully as possible and he produced a very wide range of material on the Bugis over many years, including films and collections of material culture. He was one of the founders of Archipel journal, and played a significant role in the direction of French research in Southeast Asia.]

3 Emeritus Professor Macknight is a Fellow in the Research School of Asian and Pacific Studies, The Australian National University, Canberra, Australia. He has longstanding interests in the Makassar-based trepang industry in northern Australia, pre- and proto-history in South Sulawesi and Bugis philology.

4 The Bugis, of whom there are about 3 million, live mainly in the southwestern peninsula of Sulawesi (Celebes) in Indonesia. From here, they have spread across the whole archipelago, particularly to the west and east coasts of Kalimantan (Borneo), to East Sumatra and the southern part of the Malay Peninsula. For a general account, see Pelras, Ch., "Missions en Malaisie et en Indonésie," ASEMI 3/2 (1972): 135-172. [Now reprinted in Pelras, Explorations: 9-24. See also Pelras, Ch., The Bugis (Oxford: Blackwell, 1996).]

5 I am only speaking here of oral literatures coexisting with a written literary tradition.

6 Pelras, Ch., "Introduction à la Littérature Bugis," Archipel 10 (1975): 239-267. [Now reprinted in Pelras, Explorations: 71-84.]

7 Damais, L-C., "L'écriture Bougie," in Notices sur les caractères étrangers anciens et modernes réunis par Ch. Fossey (Paris: Imprimerie Nationale, 1948: 375-380). [This 
matter is under much current discussion. A case for ultimate derivation from Gujarat in northern India is made in Miller, C. R., "Devanagari's descendants in North and South India, Indonesia and the Philippines," Writing Systems Research 6 (2013): 10 24, http://dx.doi.org/10.1080/17586801.2013.857288.]

[The best edition of the Gowa and Tallo' chronicles is now Cummings, W. P., A chain of kings: The Makassarese chronicles of Gowa and Talloq (Leiden: KITLV Press, 2007). See pages 32 and 85 for the relevant passages. These and other passages are discussed in detail in Fachruddin Ambo Enre, Ritumpanna Wélenrénngé: Sebuah episoda sastra Bugis klasik Galigo (Jakarta: Ecole Française d'ExtrêmeOrient/Fakultas Sastra Universitas Indonesia/Yayasan Obor Indonesia, 1999: 34-40.)]

My transcription of Bugis generally follows the most current modern usage among the Bugis themselves and not the system of the linguists of the Balai Bahasa (Language Institute) in Makassar, which is still the subject of discussion. I therefore follow the conventions of the modern spelling of Indonesian and Malaysian (ejaan yang disempurnakan), with the following differences:

- A distinction is made between the weak /e/ (schwa or pepet) and the strong /é/ (Bugis with typewriters which lack the key for /é/, often take the trouble use the hyphen key to add a macron above the /e/ for this vowel.)

- A glottal stop at the end of a word is indicated by an apostrophe, /'/

- With the exception of $/ \mathrm{bb} /$ and $/ \mathrm{dd} /$, which are preglottalised, double consonants represent geminated consonants, even /ngng/ and /nyny/.

- In addition, when the stress falls, for some special reason, on a syllable other than the penultimate, I show this with a circumflex, $/ \%$, and I use a hyphen to join to the preceding word those enclitic particles which the Bugis tend to suffix, but which the linguists write separately.

[On the matter of Bugis orthography generally, see Macknight, C. C, "Note on the orthography of Bugis," in Bugis and Makasar: Two short grammars, ed. Macknight, C. C. (South Sulawesi Studies 1, Canberra: Karuda Press, 2013: 31-32).]

10 [There has been a good deal published in recent years on the matters raised in this paragraph, as mentioned in note 7. For much useful information, see Noorduyn, J., "Variation in the Bugis/Makassarese script," Bijdragen tot de Taal-, Land- en Volkenkunde (BKI) 149 (1993): 533-570 and Fachruddin, Ritumpanna Wélenrénngé: 29-40. Caldwell argues, chiefly on the basis of the proliferation of detail in genealogies, for the adoption of writing in South Sulawesi during the 14th century. He has revised his original estimate of AD c. 1400 (reported in Macknight, C. C., The early history of South Sulawesi: Some recent advances (Clayton: Working Paper 81, Centre of Southeast Asian Studies, Monash University, 1993, 10-11) to c. 1300 (Caldwell, I. A., "The chronology of the king list of Luwu' to AD 1611," in Living through histories: Culture, history and social life in South Sulawesi, eds. Robinson, K. and Paeni, M. (Canberra: Department of Anthropology, Research School of Pacific and Asian Studies, Australian National University/National Archives of Indonesia, $1998,40)$. The La Galigo material is now generally considered to be orally composed and may not have been committed to writing until after, perhaps well after, 1600. See Macknight, The early history of South Sulawesi: 25-37, largely reporting research by Sirtjo Koolhof. For discussion of palm leaf strip rolls, see Noorduyn, "Variation": 561 and Macknight, C. C., "Changing perspectives in Island Southeast Asia," in Southeast 
Asia in the 9th to 14th centuries, eds. Marr, D. G. and Milner, A. C. (Singapore/Canberra: Institute of Southeast Asian Studies/Research School of Pacific Studies, Australian National University, 1986, 222-223. The best selection of illustrations of South Sulawesi manuscripts among several recent books on Indonesian manuscripts is to be found in Biranul Anas (ed.), Indonesia indah buku ke-9: Aksara (Jakarta: Yayasan Harapan Kita, 1997).]

11 [Noorduyn, "Variation": 537-544 provides details of these and some earlier attempts to print Bugis texts.]

12 Matthes, B. F., Kort verslag aangaande alle mij in Europa bekende Makassaarsche en Boeginesche handschriften, vooral die van het Nederlandsch Bijbelgenootschap, (Amsterdam: Nederlandsch Bijbelgenootschap, 1875) and his Vervolg op het kort verslag aangaande alle mij in Europa bekende Makassaarsche en Boeginesche handschriften, vooral die van het Nederlandsch Bijbelgenootschap (Amsterdam: Nederlandsch Bijbelgenootschap, 1881).

13 Kern, R. A., Catalogus van de Boegineesche, tot den I La Galigo-cyclus behoorende handschriften de Leidsche Universiteitsbibliotheek alsmede van die in andere Europeesche bibliotheken (Leiden: Universiteitsbibliotheek, 1939) and his Catalogus van de Boeginese, tot den I La Galigo-cyclus behoorende handschrifte van Jajasan Matthes (Matthesstichting) te Makassar (Indonesië) (Makassar: Jajasan Matthes, 1954). [There is now an Indonesian translation of these, though unfortunately it omits some crucial technical details: Kern, R. A., I La Galigo: Cerita Bugis kuno, transl. La Side and Sagimun M. D. (Yogyakarta: Seri Terjemahan KITLV-LIPI, Gadjah Mada University Press, 1989).]

14 Matthes, B. F., Boegineesche chrestomathie: Oorspronkelijke Boeginesche geschriften in proza en poëzij, van aanteekeningen voorzien en ten deele vertaald, Deel 1, (Makassar, 1864); Deel 2, (Amsterdam, 1872); Deel 3, aanteekeningen, (Amsterdam, 1872).

15 [The last few years have seen some further advances in the control and cataloguing of Bugis manuscripts, though much remains to be done. For a recent overall account, see Chambert-Loir, H. and Fathurahman, O., Khazanah naskah: Panduan koleksi naskahnaskah Indonesia sedunia (World guide to Indonesian manuscript collections) (Jakarta: Naskah and Dokumen Nusantara Seri XVI, École française d'ExtrêmeOrient/Yayasan Obor Indonesia, 1999). This work describes on pages 90-92 the outcomes of the project mentioned in the text. A very extensive range of locally-held material has been microfilmed by the Arsip Nasional in Makassar, and these microfilms have now been listed and briefly described in Mukhlis Paeni et al., Katalog induk naskah-naskah nusantara: Sulawesi Selatan (Arsip Nasional Republik Indonesia, in collaboration with The Ford Foundation, Universitas Hasanuddin, Gadjah Mada University Press, n.p., 2003). The main collection in Jakarta is listed in Behrend, T. E. (ed.), Katalog induk naskah-naskah nusantara jilid 4: Perpustakaan Nasional Republik Indonesia (Jakarta: Yayasan Obor Indonesia/École française d'Extrême-Orient, 1998). A. A. Cense's very valuable catalogue of manuscripts held in Britain appears in Ricklefs, M. C. and Voorhoeve, P., Indonesian manuscripts in Great Britain: A catalogue of manuscripts in Indonesian languages in British public collections (Oxford: Oxford University Press, 1977). Nine manuscripts held in Washington are excellently described in Tol, R., "Pengembaraan La Galigo ke 
Washington DC," in La Galigo: Menelusuri jejak warisan sastra dunia, eds. Rahman, N. et al. (Makassar: Pusat Studi La Galigo, Divisi Ilmu Sosial dan Humaniora, Pusat Kegiatan Penelitian, Universitas Hasanuddin/Permerintah Daerah Kabupaten Barru, 2003, 59-78.]

16 [For recent editions of La Galigo materials, see Fachruddin, Ritumpanna Wélenrénngé; Koolhof. S. and Tol, R. (redaksi), I La Galigo: Menurut naskah NBG 188 yang disusun oleh Arung Pancana Toa, vol. 1, (Jakarta: KITLV/Djambatan, 1995); vol. 2, (Makassar: Lembaga Penerbitan Universitas Hasanuddin, 2000); Rahman, N., Cinta, laut, dan kekuasan dalam epos La Galigo: Perspektif filologi dan semiotik (Makassar: La Galigo Press, 2006); and Koolhof, S. (trans.), "La Galigo; handel en liefde in andermans huid," in Oosterse omzwervingen: Klassieke teksten over Indonesië uit Oost en West, Leiden: KITLV Uitgeverij, 2000, 28-49. An important article is Koolhof, S., "The 'La Galigo'; A Bugis encyclopaedia and its growth," BKI 155 (1999): 362-387. There is also the very comprehensive series of papers brought together in Rahman, N. et al., La Galigo: Menelusuri jejak warisan sastra dunia, presented in a conference in Barru in 2002. For one version of La Toa, see Mattulada, Latoa: Satu lukisan analitis terhadap antropologi-politik orang Bugis (A descriptive analysis of the political anthropology of the Buginese) (Jakarta: Universitas Indonesia, 1974). Campbell Macknight and Mukhlis have an edition of the chronicle of Boné in preparation.]

17 This can have consequences for the present-day attitude of Bugis-and other Indonesians as well - in respect of copyright. In 1979, a scandal rocked Makassar; a student at Hasanuddin University recognised an entire chapter of his master's thesis (skripsi) reproduced word for word in a museum pamphlet on South Sulawesi boatsbut signed by three staff members of the museum. He wrote to the newspapers and complained to Jakarta. The signatories to the pamphlet seemed to be genuinely astonished; had they not just followed normal practice?

18 Kern, Catalogus... van Jajasan Matthes, p. v. [For another view of the size and nature of the La Galigo material, see Macknight, C. C., "La Galigo in comparative perspectives," in Rahman, N. et al., La Galigo: Menelusuri jejak warisan sastra dunia: 349-372.]

19 [On this point, see Pelras, Ch., "Le panthéon des anciens Bugis vu à travers les textes de La Galigo," Archipel 25 (1983): 63-96. Now reprinted in Pelras, Explorations: 179-203.]

20 [This paragraph needs to be read in the light of more recent work, especially Koolhof, S., "Dutana Sawérigading; Een scène uit de I La Galigo" (Scriptie Rijksuniversiteit, Leiden, 1992); relevant sections are summarised in Macknight, The early history of South Sulawesi. Archaeological work on sites mentioned in the cycle-and the problems of access to other sites - are discussed in Bulbeck, D. and Caldwell, I., Land of Iron: The historical archaeology of Luwu and the Cenrana Valley (Hull/Canberra: Centre for South-East Asian Studies, University of Hull/School of Archaeology and Anthropology, Australian National University, 2000), and Fadillah, M. A. and Sumantri, I. (eds), Kedatuan Luwu: Perspektif arkeologi, sejarah dan antropologi (Makassar: Lembaga Penerbitan Universitas Hasanuddin in collaboration with Institut Etnografi Indonesia, 2000.] 
21 As a result of this I have been able to compare certain oral traditions about historical events with the Portuguese data from the 16th century. See Pelras, Ch., "Les premières données occidentales concernant Célèbes-Sud," BKI 133 (1977): 227-260 and "Célèbes-Sud avant l'Islam, selon les premiers témoignages étrangers," Archipel 21 (1981): 153-184. [Now reprinted in Pelras, Explorations: 155-169.]

${ }^{22}$ K. M. A. Usop, "Pasang ri Kajang. Kajian sistem nilai di 'Benteng Hitam' Amma Toa" (Ujung Pandang: Laporan penelitian PLPIIS, 1978).

23 An interesting example of research conducted among a number of traditional healers in the suburbs of Makassar may be found in Sianipar, "Obat dan mantra: Segi-segi peranan dukun dalam masyarakat Bugis-Makassar" (Ujung Pandang: Laporan penelitian PLPIIS, 1977).

24 [For the results of this, see Hamonic, G., "«Mallawolo» Chants Bugis pour la sacralisation des anciens princes de Célèbes-Sud," Archipel 19 (1980): 43-79; Hamonic, G., "Du "langage des dieux" au langage de l'histoire; Quelques remarques à propos de l'historiographie Bugis de Célèbes-Sud," Archipel 20 (1980): 304-316; Hamonic, G., "Pour une étude comparée des cosmogonies de Célèbes-Sud: Á propos d'un manuscrit inédit sur l'origine des dieux Bugis," Archipel 25 (1983): 35-55 and Hamonic, G., Le Langage des dieux: Cultes et pouvoirs pré-Islamiques en pays Bugis Célèbes-Sud, Indonésie (Paris: Éditions du Centre National de la Recherche Scientifique, 1987). Another useful article is Sirk, Ü., "On old Buginese and Basa Bissu," Archipel 10 (1975): 225-237.]

25 This terminology is taken, for the most part, from Abdul Rahman Daeng Palallo, "Bahasa Bugis, dari hal Élompugi," Bingkisan Sulawesi Selatan dan Tenggara 9 (1967): 17-18; 10 (1968): 11-18.

${ }^{26}$ [For recent editions and translations of tolo', see Tol, R., Een haan in oorlog: Toloqna Arung Labuaja, een twintigste-eeuws Buginese heldendicht van de hand van I Mallaq Daéng Mabéla Arung Manajéng (Dordrecht: Verhandelingen van her Koninklijk Instituut voor Taal-, Land- en Volkenkunde [VKITLV] 141, Foris Publications, 1990) and Koolhof, S. and Tol, R., "The delight of the Dutch compagnie: On the Toloqna Musuq Boné by Daéng ri Aja," Jambatan 11/3 (1993): 99-108.]

27 Hamonic, "Mallawolo," 49.

28 [For examples, see Macknight, C. C. and Caldwell, I. A., "Variation in Bugis manuscripts," Archipel 61 (2001): 139-154.]

29 [This seems to be not always the case; for both the tolo' mentioned above in note 26, the composer is known by name.]

${ }^{30}$ [This matter has also been much discussed in respect of traditional Malay literature. For a vigorous statement of the interaction of orality and writing in this field, see Sweeney, A., "Aboard two ships: Western assumptions on medium and genre in Malay oral and written traditions," in Recovering the orient: Artists, scholars, appropriations, eds. Gerstle, A. and Milner, A. (Chur: Harwood, 1994): 317-338.]

31 [This assessment of the continuing role of bissu is perhaps too pessimistic. See Davies, S. G., Gender diversity in Indonesia: Sexuality, Islam and queer selves (London and New York: Routledge, 2010); Lathief, H., "Kepercayaan orang Bugis di Sulawesi Selatan: Suatu kajian antropologi budaya" (doctoral diss., Program Pascasarjana, Universitas Hasanuddin, Makassar, 2005); and Latief, H., "Bissu: Iman 
yang menghibur," in La Galigo: Menelusuri jejak warisan sastra dunia, eds. Rahman, N. et al.: 517-533.]

32 This applies to the long, liturgical texts of the Toraja, to take an example from a neighbouring society which is fairly comparable with the Bugis. See van de Veen, H., The Merok feast of the Sa'dan Toraja ('s-Gravenhage: VKITLV 45, M Nijhoff, 1965) and The Sa'dan Toraja chant for the deceased ('s-Gravenhage: VKITLV 49, M. Nijhoff, 1966). [Now also van der Veen, H. Overleveringen en zangen der ZuidToradja's ('s-Gravenhage: VKITLV 85, M. Nijhoff, 1979).]

33 [On the metrics of La Galigo text, see Sirk, Ü, "A contribution to the study of Buginese metrics: La Galigo verse," BKI 142 (1986): 277-295. As Sirk shows in this excellent article, there are many segments with more than one stress and also occasional cases, such as the third segment here, in which the stress falls on the third last syllable.]

34 Matthes, Boeginesche chrestomathie, 2: 443-444. [The vertical lines at the end of some lines mark the only punctuation in the original.]

35 The details of these stories are drawn from Matthes' catalogue.

${ }^{36}$ [See Pelras, Ch., "Maître chevrotain à Célèbes-Sud," ASEMI 11 (1980): 365-377. Now reprinted in Pelras, Explorations: 145-154.]

37 According to Antonio de Paiva, a Portuguese whose account dates from 1545, the Malays had been present in the port of Siang for about 60 years. Since then, the Malay community has played an important role. Until the beginning the 20th century, they were organised under the command of a "captain." [For more detail, see Pelras, "Les premières données occidentales." Another useful source on Malay literary and other influences is Cense, A. A., "Maleise invloeden in het oostelijk deel van de Indonesische archipel," BKI 134 (1978): 415-432.]

38 "Pau-pau rikadong," in Matthes, Boeginesche chrestomathie, 1: 1, lines 1-3.

39 Corita I Meuridi, a story told by Kapala Toa from Sidenreng-Rappang, collected and transcribed by Mursalim Amri, 1978.

40 "Pau-pau rikadong," in Matthes, Boeginesche chrestomathie, 1: 2, lines 7-9.

41 Ana' datu ripalié, a story told by Wa' Ile', from Amparita, collected and transcribed by Mursalim Amri, 1978.

42 "Pau-pau rikadong," in Matthes, Boeginesche chrestomathie, 1: 2, line 21.

43 Coritana bélésué, a story told by Kapala Toa from Sidenreng-Rappang, collected and transcribed by Mursalim Amri, 1978.

44 [See Tol, R., "Rolled up Bugis stories: Marriage advice and the tale of the parakeet," Review of Indonesian and Malaysian Affairs 43 (1) (2009): 189-208.]

45 Tolona to Senrima Wé Denradatu Bessé Langélo Daéng ritikka raja pataunna tanaé Tellu Limpoé riterrinna ri Balandaé ri taung 1829 (Lembaga Sejarah dan Antropologi, 1974): 44.

46 La Padoma Ennaja, an oral version recited by La Dallé' Ambo' Baha, from Kampung Baru, Parepare, recorded and transcribed by Mursalim Amri, 1978.

47 Riwaya'na passompe' poléwé ri Bidu'-bidu', an anonymous commercial cassette, transcribed by Paléwai, 1978.

48 Performance by Laruna on a commercial cassette devoted for the most part to the story of La Guliling. It has been transcribed by Paléwai, 1973. 
49 Contract of governance between the people of Wajo' and the Arung Siméttempola to Taba (c. 1480) quoted in Abdurrazak Daéng Patunru, Sedjarah Wajo' (Makassar: Jajasan Kebudayaan Sulawesi Selatan dan Tenggara, 1965): 38.

50 Sianipar, "Obat dan mantra": 79. 